CLINICAL STUDY

\title{
Effect of somatostatin infusion on peptide YY secretion: studies in the acute and recovery phase of anorexia nervosa and in obesity
}

Antonello E Rigamonti, Silvano G Cella, Sara M Bonomo, Giuseppe Mancia ${ }^{1}$, Guido Grassi ${ }^{1}$, Mario Perotti ${ }^{1}$, Fiorenza Agosti ${ }^{2}$, Alessandro Sartorio ${ }^{2,3}$, Eugenio E Müller and Angela I Pincelli ${ }^{1}$

Department of Medical Pharmacology, University of Milan, Via Vanvitelli 32, 20129 Milan, Italy, ${ }^{1}$ Internal Medicine, San Gerardo Hospital, University of Milan Bicocca, Monza, Italy, ${ }^{2}$ Istituto Auxologico Italiano, IRCCS, Experimental Laboratory for Auxo-endocrinological Research and ${ }^{3}$ Division of Metabolic Diseases, Istituto Auxologico Italiano, Piancavallo (VB), Italy

(Correspondence should be addressed to A E Rigamonti; Email: antonello.rigamonti@guest.unimi.it)

\begin{abstract}
Objective: Changes in many gastrointestinal peptides, including the anorexigenic peptide YY (PYY), which is produced by L cells, occur in both anorexia nervosa (AN) and obesity (OB). High PYY levels are present in AN, whereas in morbid $\mathrm{OB}$ fasting and postprandial PYY secretion is blunted. Somatostatin (somatotropin release-inhibiting factor (SRIF)) reportedly inhibits plasma PYY concentrations in animals and healthy humans, but the effect of a SRIF infusion on spontaneous PYY secretion in AN and OB is unknown.

Methods: A total of 18 young women, seven with acute AN (A-AN), four with AN in the recovery phase $(\mathrm{R}-\mathrm{AN})$, and seven with morbid $\mathrm{OB}$, were studied. All subjects underwent an infusion of SRIF $(9 \mu \mathrm{g} / \mathrm{kg}$ i.v./h, over $60 \mathrm{~min}$ ), with blood samples drawn before and at different time intervals after SRIF administration. Plasma PYY levels were measured at each time point.

Results: SRIF significantly inhibited plasma PYY concentrations in R-AN and OB, without affecting PYY titers in A-AN. In OB, the inhibitory effect of SRIF also persisted at $90 \mathrm{~min}$. Withdrawal of SRIF infusion in R-AN resulted in a prompt restoration of basal plasma PYY levels, whereas termination of SRIF infusion in OB was followed by a slower increase of PYY titers toward baseline levels. After infusion, PYY $\Delta$ area under the curve $(\triangle \mathrm{AUC})$ in R-AN was significantly higher than those in A-AN and $\mathrm{OB}$ patients. A significant difference in PYY $\triangle \mathrm{AUC}$ between $\mathrm{A}-\mathrm{AN}$ and $\mathrm{OB}$ was present.

Conclusions: These results suggest the existence of a hypo- and hyper-sensitivity of $\mathrm{L}$ cells to the inhibitory effect of SRIF in A-AN and OB respectively.

European Journal of Endocrinology 165 421-427
\end{abstract}

\section{Introduction}

Somatostatin (somatotropin release-inhibiting factor (SRIF)) is composed of two principal bioactive molecular forms, SRIF14 and SRIF28, derived through differential processing of a common prosomatostatin precursor (1). The gastrointestinal tract provides the largest source of SRIF and shows relatively selective distribution of the two molecular forms $(2,3)$.

The biological effects of SRIF are mediated by five distinct receptors (SSTR1-5) that are widely expressed in the $\mathrm{CNS}$ and the periphery, including the gastrointestinal tract (4-18).

Peptide YY (PYY) is a 36-amino acid peptide synthesized and released into the circulation from specialized enteroendocrine cells, called L cells, predominantly located in the distal gastrointestinal tract (19).

In this study, two main forms of PYY have been described: $\mathrm{PYY}_{1-36}$ and $\mathrm{PYY}_{3-36}$ (20). Importantly,
$\mathrm{PYY}_{3-36}$ is the main circulating form of the peptide both in the fasted and in the fed states (21-23).

Circulating PYY levels increase promptly in response to nutrient ingestion, caloric load, food consistency, and nutrient composition $(22,24,25)$. The initial postprandial rise in circulating PYY occurs within $15 \mathrm{~min}$ of food ingestion, before nutrients have reached the L cells of the distal gastrointestinal tract, implying the existence of a neural or hormonal mechanism in this release process. Typically, plasma PYY peak occurs 1-2 $\mathrm{h}$ postprandially, followed by a plateau phase of several hours (26).

Peripheral administration of PYY reduces food intake in rodents and normal-weight humans (27). Reportedly, the anorectic effect of PYY is preserved in patients with morbid obesity (OB), who under baseline conditions exhibit reduced fasting and postprandial levels of the peptide (28). Along this line, a negative association between PYY concentrations and markers of adiposity 
has been reported in some, but not all, studies in adults, children, and infants (28-34).

In contrast to $\mathrm{OB}$ subjects, increased fasting and meal-stimulated PYY levels are present in patients with anorexia nervosa (AN), suggesting that the peptide may play a physiopathological role in this eating disorder (34-37).

Previous studies in animal models have shown that SRIF is a potent inhibitor of PYY secretion (10). In addition, SRIF has been reported to inhibit PYY postprandial response also in healthy subjects (38), but the effect of SRIF on PYY secretion in AN and OB is presently unknown.

Therefore, based on the foregoing, we studied the effect of a SRIF14 infusion on spontaneous PYY release in patients with $\mathrm{AN}$, in the acute phase $(\mathrm{A}-\mathrm{AN})$ or recovery phase (R-AN) of the disease, and in $\mathrm{OB}$ subjects.

\section{Materials and methods}

\section{Subjects and methods}

A total of 18 young women (seven patients with A-AN, aged 19-33 years; four with R-AN, aged 17-32 years; and seven with morbid OB, aged 17-29 years) were studied.

Clinical and hormonal characteristics of the study subjects are shown in Table 1. All AN patients met the diagnostic criteria for AN according to the Diagnostic and Statistical Manual of Mental Disorders IV-TR (39). Patients were defined having R-AN when, after a complex program adopted for AN, consisting of nutritional rehabilitation, individual psychotherapy, family therapy, and behavioral counseling in both inpatient and outpatient setting, they gained a stable low normal weight, and became eumenorrheic for at least 6 months (40); for R-AN patients, the duration of the R-AN was $15.8 \pm 4.0$ months. All subjects gave informed consent to participate in the study, which had been approved by the local ethics committee. OB subjects (body mass index $(\mathrm{BMI})>30 \mathrm{~kg} / \mathrm{m}^{2}$ ) had no history or actual evidence of endocrine or psychiatric disorders and had not been taking medications in the previous 6 months. Being eumenorrheic, all patients with R-AN and OB were studied in the early follicular phase of the menstrual cycle. Patients with A-AN were amenorrheic.

After an overnight fast, an indwelling (i.v.) cannula was inserted in both forearms at $0800 \mathrm{~h}$ for separate blood sampling and drug administration. SRIF (SRIF14; Stilamin; Serono, Rome, Italy) was infused i.v. in $50 \mathrm{ml}$ normal physiological saline at a rate of $9 \mu \mathrm{g} / \mathrm{kg}$ per $\mathrm{h}$ over $60 \mathrm{~min}$ (0-60 min of the study), with blood samples drawn at $-30,0,30,45,60,90,105,120$, 135 , and $150 \mathrm{~min}$. Plasma PYY levels were measured at each time interval.

The dose of SRIF was chosen based on its effectiveness to inhibit GH secretion in A-AN (41). Anyway, serum GH levels were measured before, during, and after SRIF infusion (i.e. at 0,30 , and $60 \mathrm{~min}$ ).

Baseline plasma levels of estradiol $\left(\mathrm{E}_{2}\right)$, free triiodothyronine $\left(\mathrm{FT}_{3}\right)$, free thyroxine $\left(\mathrm{FT}_{4}\right)$, TSH, IGF1, and immunoreactive insulin (IRI) were measured once at $-30 \mathrm{~min}$ before SRIF infusion.

Total plasma PYY, including both $\mathrm{PYY}_{1-36}$ and $\mathrm{PYY}_{3-36}$, was measured by a commercially available RIA for PYY (Linco Research, Saint Charles, MO, USA). The sensitivity of the method was $10 \mathrm{pg} / \mathrm{ml}$; intra- and inter-assay coefficients of variation (CVs) were 2.9 and $7.1 \%$ respectively.

Serum GH levels were estimated by chemiluminescence immunoassay (Nichols Advantage, Nichols Institute Diagnostics, San Juan Capistrano, CA, USA); sensitivity of the assay is $0.01 \mathrm{ng} / \mathrm{ml}$, intraand inter-assay CVs were 4.4 and $8.6 \%$ respectively. Serum IGF1 levels were estimated by chemiluminescence immunoassay (Nichols Advantage, Nichols Institute Diagnostics); sensitivity of the assay was $6 \mu \mathrm{g} / \mathrm{l}$, intra- and inter-assay CVs were 4.2 and $6.3 \%$ respectively. Serum IRI was measured by electrochemiluminescence immunoassay (ECLIA; Roche Diagnostics $\mathrm{GmbH}$ ); sensitivity of the assay was $0.2 \mu \mathrm{U} / \mathrm{ml}$; intra- and inter-assay $\mathrm{CVs}$ were 4.2 and $8.2 \%$, respectively; and normal range in our laboratory was $2.6-24.9 \mu \mathrm{U} / \mathrm{ml}$. Serum TSH was measured by ECLIA (Roche Diagnostics); sensitivity of the assay was $0.005 \mathrm{mU} / \mathrm{l}$; intra- and inter-assay $\mathrm{CVs}$ were 5.4 and $8.7 \%$, respectively; and normal range was $0.27-$ $4.2 \mathrm{mU} / \mathrm{l}$. Serum $\mathrm{FT}_{4}$ was measured by ECLIA (Roche Diagnostics); sensitivity of the assay was $0.30 \mathrm{pmol} / \mathrm{l}$; intra- and inter-assay CVs were 4.8 and $6.6 \%$, respectively; and normal range $12-22 \mathrm{pmol} / \mathrm{l}$. Serum $\mathrm{FT}_{3}$ was measured by ECLIA (Roche Diagnostics);

Table 1 Demographic and hormonal characteristics of the study subjects. Data are expressed as mean \pm S.E.M.

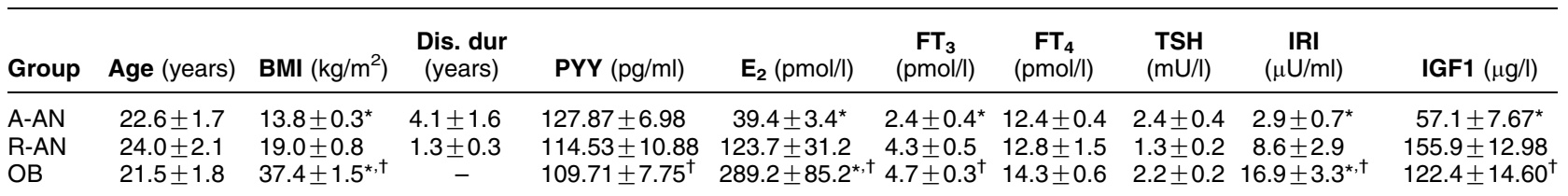

${ }^{*} P<0.01$ versus $\mathrm{R}-\mathrm{AN} ;{ }^{\dagger} P<0.01$ versus A-AN. Dis. dur, disease duration. 
sensitivity of the assay was $0.4 \mathrm{pmol} / \mathrm{l}$; intra- and interassay CVs were 5.1 and $9.0 \%$, respectively; and normal range was $2.8-7.1 \mathrm{pmol} / \mathrm{l}$. Serum $\mathrm{E}_{2}$ was measured by ECLIA (Roche Diagnostics); sensitivity of the assay was $18.4 \mathrm{pmol} / \mathrm{l}$; intra- and inter-assay CVs were 4.9 and $6.2 \%$, respectively; and normal range for the follicular phase of the menstrual cycle was 90.1-716 pmol/l.

No adverse effects were recorded during the test.

\section{Statistical analysis}

A specific statistical software package (Prism 5, GraphPad Software, San Diego, CA, USA) was used for data analysis and graphing.

Results are expressed as mean \pm s.E.M. To facilitate comparison of the PYY secretory profiles during the test, plasma PYY concentrations were expressed either as absolute values or as PYY $\Delta$ area under the curve ( $\triangle \mathrm{AUC} ; \Delta \mathrm{AUC}$ detected after withdrawal of SRIF infusion minus the value of the plasma PYY level at $t_{60}$ multiplied by $90 \mathrm{~min}$ in each subject). To demonstrate the effectiveness of the infused dose of SRIF, the SRIF-induced inhibition of serum GH levels was calculated as $\triangle \mathrm{AUC}$ (i.e. AUC detected during SRIF infusion minus the value of the serum $\mathrm{GH}$ level at $t_{60}$ multiplied by $60 \mathrm{~min}$ in each subject).

Plasma PYY concentrations were compared within each group and among all groups using a two-way ANOVA with repeated measures followed by the post hoc Tukey's test. One-way ANOVA was used to compare PYY $\triangle$ AUCs of the three groups as well as the other demographic and hormonal characteristics of the study subjects. Correlations between baseline PYY levels or PYY $\triangle$ AUCs and the other parameters were performed by linear regression analysis.

A $P$ value of 0.05 was chosen as statistically significant.

\section{Results}

Table 1 shows the mean values \pm s.E.m. for age, BMI, PYY, $\mathrm{E}_{2}, \mathrm{FT}_{3}, \mathrm{FT}_{4}, \mathrm{TSH}, \mathrm{IGF} 1$, and IRI in A-AN, R-AN, and $\mathrm{OB}$ women. For $\mathrm{A}-\mathrm{AN}$ and R-AN, the duration of the condition is also reported.

Serum GH levels were significantly inhibited by SRIF infusion in A-AN and R-AN (GH at 0 vs 60 min: $4.17 \pm 0.85$ vs $0.90 \pm 0.41 \mathrm{ng} / \mathrm{ml}$ in $\mathrm{A}-\mathrm{AN}$ and 4.92 \pm 2.89 vs $0.48 \pm 0.18 \mathrm{ng} / \mathrm{ml}$ in $\mathrm{R}-\mathrm{AN}, \quad P<0.01$; $\triangle \mathrm{AUC}:-122.30 \pm 2.88 \mathrm{ng} / \mathrm{ml} \times \min$ in $\mathrm{A}-\mathrm{AN}$ and $-176.70 \pm 50.64 \mathrm{ng} / \mathrm{ml} \times \min$ in $\mathrm{R}-\mathrm{AN})$, whereas no statistically significant difference was found in serum $\mathrm{GH}$ levels in OB before and after SRIF infusion $(0.07$ \pm 0.02 vs $0.05 \pm 0.01 \mathrm{ng} / \mathrm{ml} ; \quad \Delta$ AUC: -20.00 $\pm 11.10 \mathrm{ng} / \mathrm{ml} \times \mathrm{min})$, indicating the effectiveness of the infused dose of SRIF.

Baseline plasma PYY concentrations were significantly higher in A-AN than in OB (127.9 \pm 7.0 vs
$109.7 \pm 7.8 \mathrm{pg} / \mathrm{ml}, P<0.001)$, and the same was true for R-AN patients $(114.5 \pm 10.9 \mathrm{pg} / \mathrm{ml})$, although the difference did not reach statistical significance. Baseline plasma PYY concentrations were lower in OB than in R-AN patients, but with no statistical significance (Table 1).

Plasma PYY concentrations from 30 up to $150 \mathrm{~min}$ were significantly lower in $\mathrm{R}-\mathrm{AN}$ than in $\mathrm{A}-\mathrm{AN}$ $(P<0.01)$ and remained persistently higher in A-AN than in $\mathrm{OB}$ patients $(P<0.001$ at all time points). No differences were found in PYY profiles of R-AN and OB patients, except for plasma PYY concentrations at $t_{90}$ $(P<0.05$; Fig. 1).

SRIF significantly inhibited plasma PYY concentrations (at 30, 45, and $60 \mathrm{~min}$ ) in R-AN and $\mathrm{OB}$, without affecting those of A-AN $(P<0.001)$ patients. In $\mathrm{OB}$, the inhibitory effect also persisted at $90 \mathrm{~min}$ $(P<0.001$; Fig. 1).

Percent inhibition of plasma PYY concentrations from $t_{0}$ to $t_{60}$ during SRIF infusion was significantly higher in R-AN and OB than in A-AN (29.2 \pm 2.3 and $31.5 \pm 3.1 \%$ vs $14.5 \pm 4.2 \%$, respectively, $P<0.001$ ), although no difference was present between R-AN and OB patients (data not shown).

SRIF infusion withdrawal in R-AN resulted in a prompt rise in plasma PYY levels from $81.1 \pm 7.9 \mathrm{pg} / \mathrm{ml}$ at $t_{60}$ to $119.0 \pm 13.5 \mathrm{pg} / \mathrm{ml}$ at $t_{90}(P<0.001)$, whereas termination of SRIF infusion in OB was followed by a sluggish rise in plasma PYY levels from 75.2 $\pm 2.4 \mathrm{pg} / \mathrm{ml}$ at $60 \mathrm{~min}$ to a maximum of 99.1 $\pm 12.6 \mathrm{pg} / \mathrm{ml}$ at $135 \mathrm{~min}(P<0.001$; Fig. 1$)$.

PYY $\Delta$ AUC in R-AN $(1674.9 \pm 110.0 \mathrm{pg} / \mathrm{ml} \times \min )$ was significantly higher than that in A-AN (782.3 $\pm 122.0 \mathrm{pg} / \mathrm{ml} \times \min , \quad P<0.001)$ and $\mathrm{OB}(1072.7$ $\pm 222.0 \mathrm{pg} / \mathrm{ml} \times \min , P<0.001)$ patients. There was

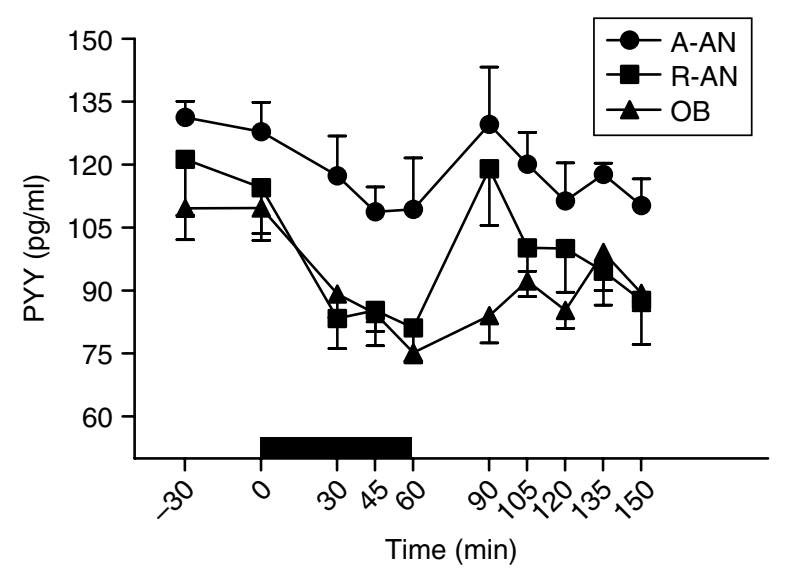

Figure 1 Plasma PYY concentration profiles (mean \pm s.E.M.) of patients with anorexia nervosa in the acute (A-AN) and recovery (R-AN) phases and subjects with obesity (OB) administered a $1 \mathrm{~h}$ infusion of SRIF ( $9 \mu \mathrm{g} / \mathrm{kg}$ per $\mathrm{h}$ i.v.). Bar indicates timing and duration of infusion. See text for intra- and inter-group statistically significant differences. 


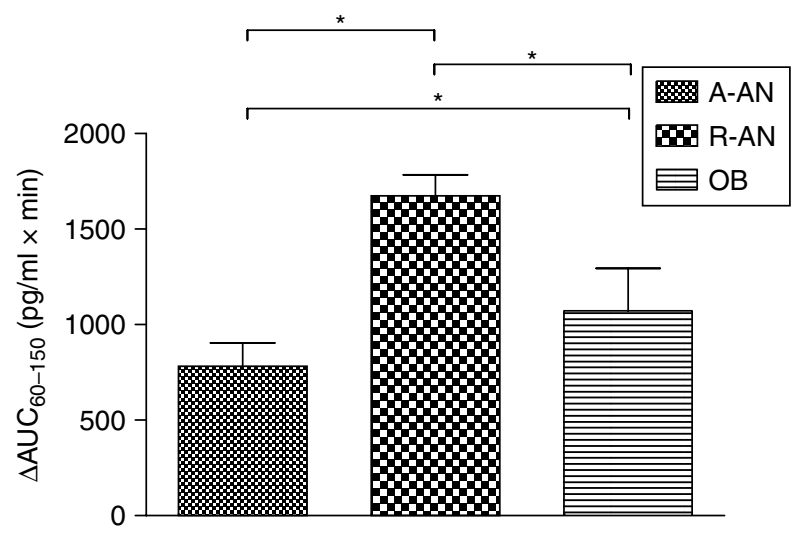

Figure 2 Plasma PYY $\triangle A U C$ (mean \pm S.E.M.) of A-AN, R-AN, and OB patients administered a $1 \mathrm{~h}$ infusion of SRIF ( $9 \mu \mathrm{g} / \mathrm{kg}$ per $\mathrm{h}$ i.v.). $\triangle A U C$ s were calculated as area under the curve after withdrawal of SRIF infusion minus the value of the plasma PYY level at $t_{60}$ multiplied by $90 \mathrm{~min}$ in each subject. Brackets and asterisks indicate groups that are statistically different. ${ }^{*} P<0.001$.

a significant difference in PYY $\triangle \mathrm{AUC}$ between $\mathrm{A}-\mathrm{AN}$ and OB $(P<0.001$; Fig. 2).

Among the possible correlations between basal PYY levels and PYY $\triangle$ AUCs after SRIF infusion withdrawal and clinical or hormone parameters, of interest were the negative correlations between baseline PYY levels and BMI $(r=-0.52 ; P<0.01)$, IRI $(r=-0.61 ; P<0.05)$, or IGF1 ( $r=-0.49 ; P<0.05$; Fig. 3$)$.

\section{Discussion}

In this study, baseline plasma PYY concentrations were significantly higher in A-AN than in OB; conversely, there were no statistically significant differences in baseline PYY levels between A-AN and R-AN or between $\mathrm{OB}$ and R-AN.

Our data confirm those reported in patients with AN (42) and bulimia nervosa (43), in whom PYY concentrations were not significantly different from those present in controls. Either of these studies, like ours, examined a small number of subjects; therefore, lack of power might account for the absence of a statistically significant difference between the groups (A-AN versus R-AN and R-AN versus OB). In this context, in another study, conducted in a larger number of subjects, higher PYY levels were found in AN patients than in healthy girls (36).

R-AN subjects might represent an 'inappropriate' control group and be actually a limit of our study. Weight recovery in AN is reportedly associated per se toward a decrease in PYY levels (36); hence, in our study, the change in PYY levels with weight recovery would probably have been more profound if more weight-recovered patients had been evaluated. Further studies in a larger population of R-AN patients are mandatory to determine whether a change in BMI predicts an inverse change in PYY levels.

Our data are consistent with previous studies in OB, which have disclosed lower (fasting and postprandial) PYY levels than in controls $(23,28,29)$.

Along with the previous considerations, in a simplified way of thinking, this suggests that in $\mathrm{OB}$, low PYY levels may lead to increased food intake, whereas, conversely, in AN high PYY levels may contribute to decreasing food intake $(19,28.44,45)$.
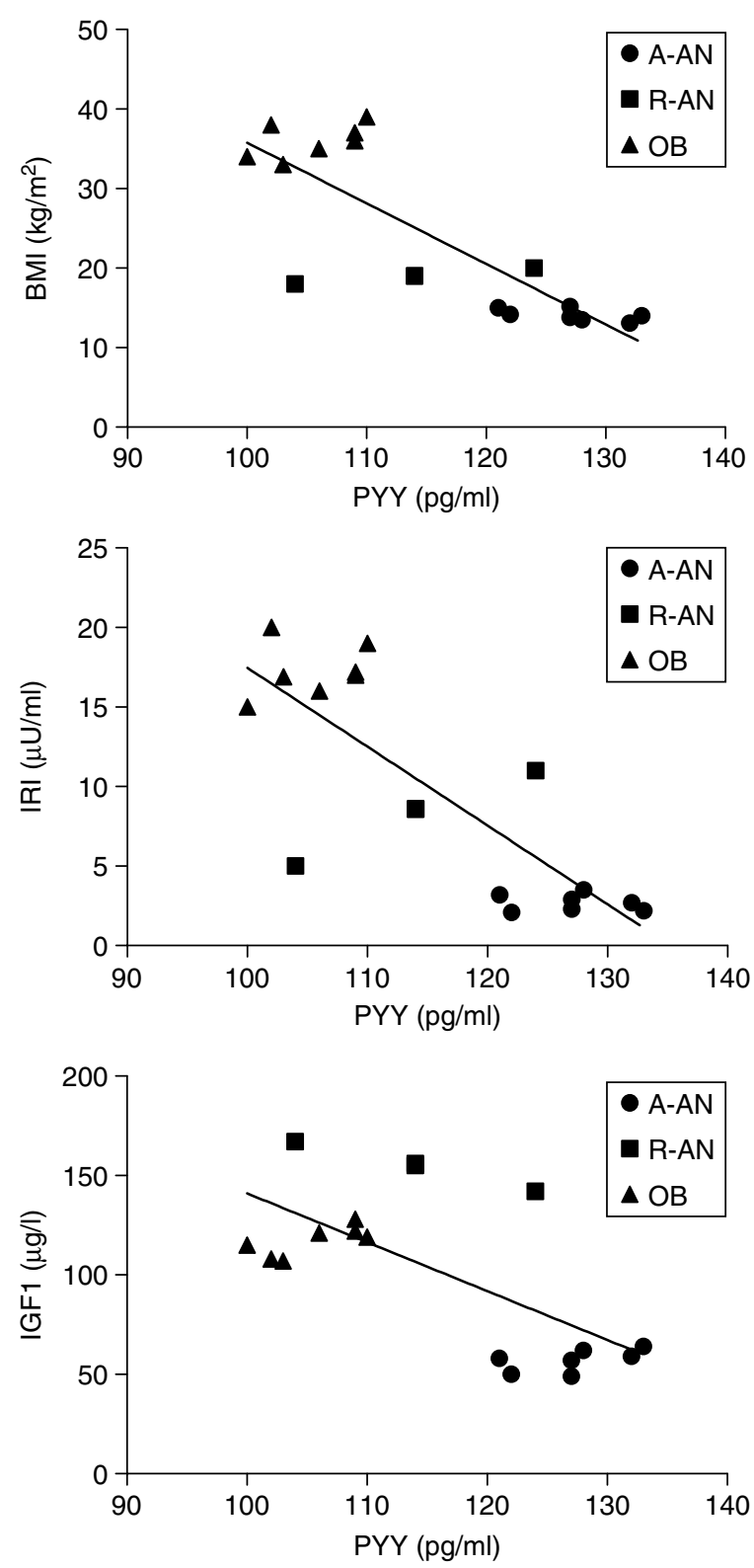

Figure 3 Correlations (for all data) between baseline PYY levels and BMI ( $r=-0.52 ; P<0.01$; top panel), IRI $(r=-0.61 ; P<0.05$; middle panel), or IGF1 ( $r=-0.49 ; P<0.05$; bottom panel). 
SRIF is known to possess a remarkable inhibitory effect on many gastroenteropancreatic hormonal secretions and functions (46).

This study shows (for the first time) that SRIF inhibits spontaneous secretion of PYY not only in R-AN but also in OB. This finding is consistent with previous studies in animal models and humans, in which SRIF was shown to be a potent inhibitor of fasting and postprandial PYY secretion $(10,38)$.

At present, the mechanisms underlying the inhibitory effect of SRIF on PYY secretion are unknown, but likely to reflect direct activation of SRIF receptors, which are widely expressed in the gastrointestinal mucosa $(4,5)$.

SRIF14 has generally been regarded as the only bioactive molecular form of SRIF regulating inhibition of gut endocrine secretion, whereas the inhibitory role of SRIF28 would have been limited to modulating pituitary hormones (15) and insulin (47). In contrast to this view, however, Chisholm \& Greenberg (48) have shown that SRIF2 8 is the principal bioactive molecular form of SRIF mediating inhibition of PYY secretion from rat intestinal cell cultures: in this context, either SRIF molecular form caused dose-dependent inhibition of PYY secretion when stimulated by gastrin-releasing peptide (GRP), the principal hormone regulating PYY release (49). However, SRIF28 was 300-fold more potent than SRIF14 and, interestingly, it would mediate inhibition of GRP-stimulated PYY secretion through activation of SSTR 5 (48), the isoform endowed with a higher affinity for SRIF28 than for SRIF14 (6).

In this study, only SRIF14 was administered and an inhibition of $\sim 30 \%$ was found on PYY secretion in R$\mathrm{AN}$ and $\mathrm{OB}$, suggesting the involvement of other SSTR isoforms (e.g. SSTR1-4) in these effects. Finally, a direct interaction between SRIF14 and SSTR 5 may not be ruled out in our study, as the pharmacological dose of SRIF used in this study was capable of strikingly inhibiting GH secretion in A-AN and R-AN (41).

The main finding of our study was the inability of SRIF to inhibit PYY secretion in A-AN patients and the lack of any rebound rise at the withdrawal of SRIF infusion (i.e. reduced PYY $\Delta$ AUC). This pattern contrasts the SRIF-induced inhibition of fasting and postprandial PYY levels of patients with Prader-Willi syndrome, who share with A-AN the hyperghrelinemia $(45,50)$.

One might hypothesize the existence of an altered sensitivity (hyposensitivity) of L cells to SRIF in A-AN. Alternatively, the unchanged PYY secretion of A-AN patients may be related to a malnourishment-dependent reduction or elevation of an unknown PYY inhibitory or stimulatory factor respectively, resulting in a persistent activation of L cells. A putative candidate could be one of the gastrointestinal hormones that are altered in A-AN (51), ruling out ghrelin, which has an inhibitory effect on PYY secretion (28).
In OB subjects, PYY secretion was promptly inhibited by SRIF, but only slowly returned to baseline levels at the termination of SRIF infusion. In contrast with A-AN, this would imply the existence of a state of hypersensitivity of L cells to SRIF in OB.

The similar percent inhibition of plasma PYY levels in $\mathrm{OB}$ and R-AN is not in contrast with this view, because PYY secretion is reduced with fasting and, taking into account the limit of detection of the analytical method we used, it is not further susceptible to inhibition by SRIF. This hypothesis should be verified, in further studies, by evaluating the inhibitory effect of SRIF on the robust PYY release elicited by a high-fat meal.

The altered sensitivity of $\mathrm{L}$ cells in $\mathrm{OB}$ might be the consequence of an adiposity-related factor, which results in a blunted synthesis and/or release of PYY. This might be the same previously alluded for explaining the findings in A-AN (see above).

Some limitations of this study have to be mentioned. First, only plasma (total) PYY levels were evaluated, disregarding other gastrointestinal peptides that influence PYY secretion (19). Second, no real control group (i.e. healthy, normal-weight subjects) could be recruited; hence, these findings should be considered cautiously. Third, the results were obtained in a reduced number of patients, though the limited spread of data should be positively considered. Finally, measurement of SRIF levels during and after infusion was not performed; therefore, differences in metabolic half-life due to disease-induced changes of plasma peptidase activity may not be ruled out.

In conclusion, elevated PYY secretion in A-AN is unaffected by an SRIF infusion, which, in contrast, inhibits plasma PYY levels in R-AN and OB, with a delayed return to baseline PYY levels in OB. Overall, the existence of a state of hypo- and hypersensitivity of $\mathrm{L}$ cells to the inhibitory effect of SRIF in A-AN and OB, respectively, may be envisaged. Though coherent with the results obtained, this interpretation might be too speculative; further studies (also in animals) are, therefore, warranted.

\section{Declaration of interest}

The authors declare that there is no conflict of interest that could be perceived as prejudicing the impartiality of the research reported.

\section{Funding}

This research did not receive any specific grant from any funding agency in the public, commercial or not-for-profit sector.

\section{References}

1 Sevarino KA, Felix R, Banks CM, Low MJ, Montminy MR, Mandel G \& Goodman RH. Cell-specific processing of preprosomatostatin in cultured neuroendocrine cells. Journal of Biological Chemistry 1987 $2624987-4993$. 
2 Newgard CB \& Holst JJ. Heterogeneity of somatostatin like immunoreactivity (SLI) in extracts of porcine, canine and human pancreas. Acta Endocrinologica 198198 564-572. (doi:10.1530/acta.0.0980564)

3 Penman E, Wass JA, Butler MG, Penny ES, Price J, Wu P \& Rees LH. Distribution and characterisation of immunoreactive somatostatin in human gastrointestinal tract. Regulatory Peptides 19837 53-65. (doi:10.1016/0167-0115(83)90281-1)

4 Bruno JF, Xu Y, Song J \& Berelowitz M. Tissue distribution of somatostatin receptor subtype messenger ribonucleic acid in the rat. Endocrinology 1993133 2561-2567. (doi:10.1210/en.133. 6.2561)

5 Krempels K, Hunyady B, O'Carroll AM \& Mezey E. Distribution of somatostatin receptor messenger RNAs in the rat gastrointestinal tract. Gastroenterology 1997112 1948-1960. (doi:10.1053/gast. 1997.v112.pm9178687)

6 O'Carroll AM, Lolait SJ, König M \& Mahan LC. Molecular cloning and expression of a pituitary somatostatin receptor with preferential affinity for somatostatin-28. Molecular Pharmacology 199242 939-946.

7 O'Carroll AM, Raynor K, Lolait SJ \& Reisine T. Characterization of cloned human somatostatin receptor SSTR5. Molecular Pharmacology 199446 291-298.

8 Yamada Y, Post SR, Wang K, Tager HS, Bell GI \& Seino S. Cloning and functional characterization of a family of human and mouse somatostatin receptors expressed in brain, gastrointestinal tract, and kidney. PNAS 199289 251-255. (doi:10.1073/pnas.89.1. 251)

9 Yamada Y, Reisine T, Law SF, Ihara Y, Kubota A, Kagimoto S, Seino M, Seino Y, Bell GI \& Seino S. Somatostatin receptors, an expanding gene family: cloning and functional characterization of human SSTR3, a protein coupled to adenylyl cyclase. Molecular Endocrinology 19926 2136-2142. (doi:10.1210/me.6.12.2136)

10 Fung L, Pokol-Daniel S \& Greenberg GR. Cholecystokinin type A receptors mediate intestinal fat-induced inhibition of acid secretion through somatostatin-14 in dogs. Endocrinology 1994 134 2376-2382. (doi:10.1210/en.134.6.2376)

11 Prinz C, Sachs G, Walsh JH, Coy DH \& Wu SV. The somatostatin receptor subtype on rat enterochromaffin like cells. Gastroenterology $1994 \mathbf{1 0 7} 1067-1074$.

12 Fung LC \& Greenberg GR. Characterization of somatostatin receptor subtypes mediating inhibition of nutrient-stimulated gastric acid and gastrin in dogs. Regulatory Peptides 199768 197-203. (doi:10.1016/S0167-0115(96)02122-2)

13 Lloyd KC, Wang J, Aurang K, Grönhed P, Coy DH \& Walsh JH. Activation of somatostatin receptor subtype 2 inhibits acid secretion in rats. American Journal of Physiology $1995 \mathbf{2 6 8}$ G102-G106.

$14 \mathrm{Gu}$ ZF, Corleto VD, Mantey SA, Coy DH, Maton PN \& Jensi RT. Somatostatin receptor subtype 3 mediates the inhibitory action of somatostatin on gastric smooth muscle cells. American Journal of Physiology 1995268 G739-G748.

15 Shimon I, Taylor JE, Dong JZ, Bitonte RA, Kim S, Morgan B, Coy DH, Culler MD \& Melmed S. Somatostatin receptor subtype specificity in human fetal pituitary cultures. Differential role of SSTR2 and SSTR5 for growth hormone, thyroid-stimulating hormone, and prolactin regulation. Journal of Clinical Investigation 199799 789-798. (doi:10.1172/JCI119225)

16 Rossowski WJ, Gu ZF, Akarca US, Jensen RT \& Coy DH. Characterization of somatostatin receptor subtypes controlling rat gastric acid and pancreatic amylase release. Peptides 199415 1421-1424. (doi:10.1016/0196-9781(94)90118-X)

17 Strowski MZ, Parmar RM, Blake AD \& Schaeffer JM. Somatostatin inhibits insulin and glucagon secretion via two receptors subtypes: an in vitro study of pancreatic islets from somatostatin receptor 2 knockout mice. Endocrinology 2000141 111-117. (doi:10.1210/ en.141.1.111)

18 Corleto VD, Severi C, Coy DH, Delle Fave G \& Jensen RT. Colonic smooth muscle cells possess a different subtype of somatostatin receptor from gastric smooth muscle cells. American Journal of Physiology 1997272 G689-G697.
19 Karra E \& Batterham RL. The role of gut hormones in the regulation of body weight and energy homeostasis. Molecular and Cellular Endocrinology 2010316 120-128. (doi:10.1016/j.mce. 2009.06.010)

20 Mentlein R, Dahms P, Grandt D \& Krüger R. Proteolytic processing of neuropeptide $\mathrm{Y}$ and peptide $\mathrm{YY}$ by dipeptidyl peptidase IV. Regulatory Peptides 199349 133-144. (doi:10.1016/01670115(93)90435-B)

21 Grandt D, Schimiczek M, Beglinger C, Layer P, Goebell H, Eysselein VE \& Reeve JR Jr. Two molecular forms of peptide YY (PYY) are abundant in human blood: characterization of a radioimmunoassay recognizing $\mathrm{PYY}_{1-36}$ and $\mathrm{PYY}_{3-36}$. Regulatory Peptides $1994 \mathbf{5 1}$ 151-159. (doi:10.1016/01670115(94)90204-6)

22 Batterham RL, Heffron H, Kapoor S, Chivers JE, Chandarana K, Herzog H, Le Roux CW, Thomas EL, Bell JD \& Withers DJ. Critical role for peptide YY in protein-mediated satiation and body-weight regulation. Cell Metabolism 20064 223-233. (doi:10.1016/j. cmet.2006.08.001)

23 Korner J, Inabnet W, Conwell IM, Taveras C, Daud A, OliveroRivera L, Restuccia NL \& Bessler M. Differential effects of gastric bypass and banding on circulating gut hormone and leptin levels. Obesity 2006 14 1553-1561. (doi:10.1038/oby.2006.179)

24 Helou N, Obeid O, Azar ST \& Hwalla N. Variation of postprandial $\mathrm{PYY}_{3-36}$ response following ingestion of differing macronutrient meals in obese females. Annals of Nutrition and Metabolism 2008 52 188-195. (doi:10.1159/000138122)

25 Chandarana K, Drew ME, Emmanuel J, Karra E, Gelegen C, Chan P, Cron NJ \& Batterham RL. Subject standardization, acclimatization, and sample processing affect gut hormone levels and appetite in humans. Gastroenterology $20091362115-2126$. (doi:10.1053/j.gastro.2009.02.047)

26 Adrian TE, Ferri GL, Bacarese-Hamilton AJ, Fuessl HS, Polak JM \& Bloom SR. Human distribution and release of a putative new gut hormone, peptide YY. Gastroenterology 198589 1070-1077.

27 Batterham RL, Cowley MA, Small CJ, Herzog H, Cohen MA, Dakin CL, Wren AM, Brynes AE, Low MJ, Ghatei MA \& Cone RD. Gut hormone PYY (3-36) physiologically inhibits food intake. Nature 2002418 650-654. (doi:10.1038/nature00887)

28 Batterham RL, Cohen MA, Ellis SM, Le Roux CW, Withers DJ, Frost GS, Ghatei MA \& Bloom SR. Inhibition of food intake in obese subjects by peptide $\mathrm{YY}_{3-36}$. New England Journal of Medicine 2003 349 941-948. (doi:10.1056/NEJMoa030204)

29 Alvarez Bartolomé M, Borque M, Martinez-Sarmiento J, Aparicio E, Hernández C, Cabrerizo L \& Fernández-Represa JA. Peptide YY secretion in morbidly obese patients before and after vertical banded gastroplasty. Obesity Surgery 200212 324-327. (doi:10.1381/096089202321088084)

30 Guo Y, Ma L, Enriori PJ, Koska J, Franks PW, Brookshire T, Cowley MA, Salbe AD, Delparigi A \& Tataranni PA. Physiological evidence for the involvement of peptide YY in the regulation of energy homeostasis in humans. Obesity 200614 1562-1570. (doi:10.1038/oby.2006.180)

31 Essah PA, Levy JR, Sistrun SN, Kelly SM \& Nestler JE. Effect of macronutrient composition on postprandial peptide YY levels. Journal of Clinical Endocrinology and Metabolism 200792 40524055. (doi:10.1210/jc.2006-2273)

32 Sodowski K, Zwirska-Korczala K, Kuka D, Kukla M, Budziszewska P, Czuba B, Włoch A, Cnota W, Bielański W, Brzozowski T, Rehfeld JF, Zdun R \& Konturek PC. Basal and postprandial gut peptides affecting food intake in lean and obese pregnant women. Journal of Physiology and Pharmacology 200758 (Supplement 1) 37-52.

33 Siahanidou T, Mandyla H, Vounatsou M, Anagnostakis D, Papassotiriou I \& Chrousos GP. Circulating peptide YY concentrations are higher in preterm than full-term infants and correlate negatively with body weight and positively with serum ghrelin concentrations. Clinical Chemistry 200551 2131-2137. (doi:10. 1373/clinchem.2005.054908) 
34 Roth CL, Enriori PJ, Harz K, Woelfle J, Cowley MA \& Reinehr T. Peptide YY is a regulator of energy homeostasis in obese children before and after weight loss. Journal of Clinical Endocrinology and Metabolism 2005 90 6386-6391. (doi:10.1210/jc.2005-1357)

35 Pfluger PT, Kampe J, Castaneda TR, Vahl T, D’Alessio DA, Kruthaupt T, Benoit SC, Cuntz U, Rochlitz HJ, Moehlig M, Pfeiffer AF, Koebnick C, Weickert MO, Otto B, Spranger J \& Tschöp MH. Effect of human body weight changes on circulating levels of peptide $\mathrm{YY}$ and peptide $\mathrm{YY}_{3-36}$. Journal of Clinical Endocrinology and Metabolism 200792 583-588. (doi:10.1210/ jc.2006-1425)

36 Misra M, Miller KK, Tsai P, Gallagher K, Lin A, Lee N, Herzog DB \& Klibanski A. Elevated peptide YY levels in adolescent girls with anorexia nervosa. Journal of Clinical Endocrinology and Metabolism 200691 1027-1033. (doi:10.1210/jc.2005-1878)

37 Nakahara T, Kojima S, Tanaka M, Yasuhara D, Harada T, Sagiyama K, Muranaga T, Nagai N, Nakazato M, Nozoe S, Naruo $\mathrm{T} \&$ Inui A. Incomplete restoration of the secretion of ghrelin and PYY compared to insulin after food ingestion following weight gain in anorexia nervosa. Journal of Psychiatric Research 200741 814-820. (doi:10.1016/j.jpsychires.2006.07. 021)

$38 \mathrm{Vu}$ MK, Van Oostayen JA, Biemond I \& Masclee AA. Effect of somatostatin on postprandial gallbladder relaxation. Clinical Physiology 200121 25-31. (doi:10.1046/j.1365-2281.2001. 00297.x)

39 American Psychiatric Association. Diagnostic and Statistical Manual of Mental Disorders IV-TR. Washington, DC: American Psychiatric Press, 2000.

40 Wagner A, Aizenstein H, Venkatraman VK, Fudge J, May JC, Mazurkewicz L, Frank GK, Bailer UF, Fischer L, Nguyen V, Carter C, Putnam K \& Kaye WH. Altered reward processing in women recovered from anorexia nervosa. American Journal of Psychiatry 2007164 1842-1849. (doi:10.1176/appi.ajp.2007.07040575)

41 Pincelli AI, Rigamonti AE, Scacchi M, Cella SG, Cappa M, Cavagnini F \& Muller EE. Somatostatin infusion withdrawal: studies in the acute and recovery phase of anorexia nervosa, and in obesity. European Journal of Endocrinology 2003148 237-243. (doi:10.1530/eje.0.1480237)

42 Stock S, Leichner P, Wong ACK, Ghatei MA, Kieffer TJ, Bloom SR \& Chanoine J-P. Ghrelin, peptide YY, glucose-dependent insulinotropic polypeptide, and hunger responses to a mixed meal in anorexic, obese, and control female adolescents. Journal of Clinical Endocrinology and Metabolism 200590 2161-2168. (doi:10. 1210/jc.2004-1251)
43 Kojima S, Nakahara T, Nagai N, Muranaga T, Tanaka M, Yasuhara D, Masuda A, Date Y, Ueno H, Nakazato M \& Naruo T. Altered ghrelin and peptide YY responses to meals in bulimia nervosa. Clinical Endocrinology 200562 74-78. (doi:10.1111/j. 1365-2265.2004.02176.x)

44 Misra M, Miller KK, Kuo K, Griffin K, Stewart V, Hunter E, Herzog DB \& Klibanski A. Secretory dynamics of leptin in adolescent girls with anorexia nervosa and healthy adolescents. American Journal of Physiology. Endocrinology and Metabolism 2005 289 E373-E381. (doi:10.1152/ajpendo.00041.2005)

45 Misra M, Miller KK, Kuo K, Griffin K, Stewart V, Hunter E, Herzog DB \& Klibanski A. Secretory dynamics of ghrelin in adolescent girls with anorexia nervosa and healthy adolescents. American Journal of Physiology. Endocrinology and Metabolism 2005 289 E347-E356. (doi:10.1152/ajpendo.00615.2004)

46 Patel YC. Somatostatin and its receptor family. Frontiers in Neuroendocrinology 199920 157-198. (doi:10.1006/frne.1999. 0183)

47 Ensinck JW, Vogel RE, Laschansky EC, Koerker DJ, Prigeon RL \& Kahn SE. Endogenous somatostatin-28 modulates postprandial insulin secretion. Immunoneutralization studies in baboons. Journal of Clinical Investigation 1997100 2295-2302. (doi:10. 1172/JCI119767)

48 Chisholm C \& Greenberg GR. Somatostatin-28 regulates GLP-1 secretion via somatostatin receptor subtype 5 in rat intestinal cultures. American Journal of Physiology. Endocrinology and Metabolism $2002 \mathbf{2 8 3}$ E311-E317. (doi:10.1152/ajpendo. $00434.2001)$

49 Brubaker PL, Drucker DA, Asa SL \& Greenberg GR. Synthesis and secretion of peptide YY by fetal rat intestinal cells in culture. Endocrinology $19911293351-3358$. (doi:10.1210/endo-129-63351)

50 Tan TM, Vanderpump M, Khoo B, Patterson M, Ghatei MA \& Goldstone AP. Somatostatin infusion lowers plasma ghrelin without reducing appetite in adults with Prader-Willi syndrome. Journal of Clinical Endocrinology and Metabolism 2004894162 4165. (doi:10.1210/jc.2004-0835)

51 Misra M \& Klibanski A. Neuroendocrine consequences of anorexia nervosa in adolescents. Endocrine Development 201017 197-214. (doi:10.1159/000262540)

Received 13 May 2011

Accepted 15 June 2011 